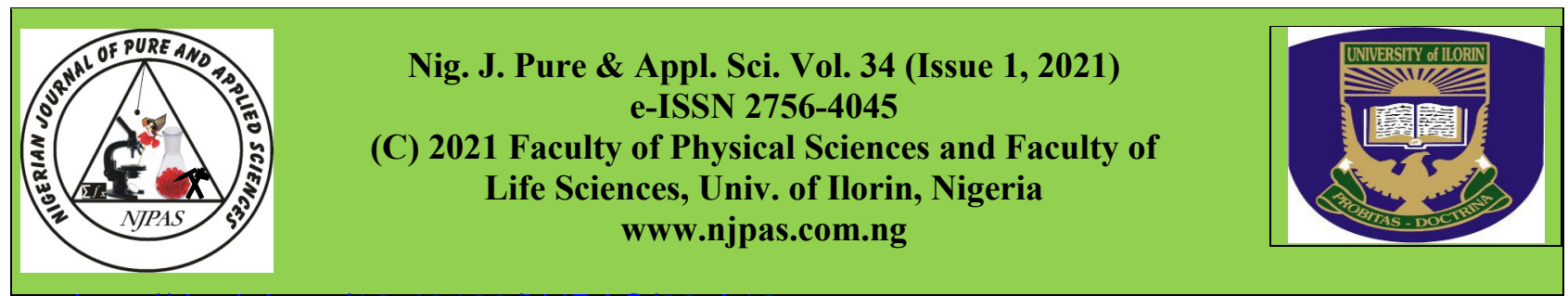

http://dx.doi.org/10.48198/NJPAS/20.A12

\title{
Effect of granular activated carbon particle sizes and depths in slow sand filter on water purification
}

\author{
K. O. Yusuf*1'; I. B. Sadiku²; S. T. Yusuff ${ }^{1}$ and S. A. Bukoye ${ }^{1}$
}

Page | $3881 \quad{ }^{1}$ Department of Agricultural and Biosystems Engineering, University of Ilorin, Ilorin, Kwara State, Nigeria ${ }^{2}$ Department of Computer Science, Gateway Polytechnic, Saapade, Ogun State

\begin{abstract}
Most rural dwellers in Nigeria depend on contaminated water from ponds, streams and wells for drinking water. Every household needs simple water purification device like Slow Sand Filter (SSF) to prevent water-borne diseases. This study was conducted to determine the effect of Granular Activated Carbon (GAC) particle sizes and depths in SSF on the purification of water. Two sets of SSF were fabricated using 6 inches $(15.24 \mathrm{~cm})$ diameter PVC pipe, fine sand (0.25 mm grain size) with $35 \mathrm{~cm}$ depth. GAC for the first set SSFs (particle sizes $10 \mathrm{~mm}, 14 \mathrm{~mm}$ with $15 \mathrm{~cm}$ depth) and GAC for the second set of the SSFs has 15 and $25 \mathrm{~cm}$ depths with particle size $10 \mathrm{~mm}$. The SSF has 50 litres storage tank from which raw water flows into the filter chamber $(15.25$ diameter and $110 \mathrm{~cm}$ long PVC). The filter was kept moist for 21 days for schmutzdecke to fully develop which is effective in trapping bacteria. Raw water was poured into the SSF, water samples were collected and analyzed using standard methods. The SSF has a capacity of producing 35 litres/h clean water. Percentage reduction of Lead, Manganese, Copper, Iron, Turbidity and Total Coliform Counts of the filtered water compared with the control were $91.35-99.88 \%, 90.00-98.33 \%, 42.00-100.00 \%, 46.67-100.00 \%, 13.04-99.15 \%$ and $16.67-57.69 \%$, respectively. The SSF increased $\mathrm{pH}$ and Calcium by $7.14-27.71 \%$ and $83.65-98.21 \%$, respectively. SSF with 10 $\mathrm{mm}$ and $25 \mathrm{~cm}$ depths GAC reduced the pollutants than the other two filters and it is recommended for purifying pond water.
\end{abstract}

Keywords: Slow sand filter; granular activated carbon; water quality; water borne diseases; paired t-test; water pollution

\section{Introduction}

Many people in rural areas of Nigeria do not have access to tap water (potable water) and they depend mainly on pond, spring, stream, lake and well water for drinking water and for other domestic uses (Yusuf and Murtala, 2020). Water from those sources are normally polluted with some chemicals and pathogens that are harmful to human health
(Hammer and Hammer, 2012). Ashbolt (2004) pointed out that lack of proper sanitation and potable water is a major source of gastrointestinal diseases in some developing countries. Contamination of surface and underground water by heavy metals normally originate from anthropogenic activities such as draining of

\section{Corresponding Author: K. O. Yusuf}

Department of Agricultural and Biosystems Engineering, University of Ilorin, Ilorin, Kwara State, Nigeria. Email: kamaru.yusuf@yahoo.com or yusuf.ok@unilorin.edu.ng 
sewerage, dumping of hospital wastes and recreational activities. Some metals that are discarded at the dumping site could decompose, bush burning and leaching of chemicals from rock could pollute both surface and underground water

Page | 3882 (Fermandez and Olalla, 2000). Water from streams, ponds, lake and uncovered well are normally contaminated with pathogens that can cause water-borne diseases such as typhoid, cholera and other deadly diseases to man (Hammer and Hammer, 2012). There is need for purification of water from ponds, streams and wells in the rural areas and some wells in urban areas that having high concentration of heavy metals using a simple and low-cost water treatment equipment. Boiling of water in the rural areas is not economical though it could destroy pathogens from the water but could not remove some hazardous chemicals like cadmium, lead, manganese and organic compounds which could cause cancer and other diseases to man. Ankidawa and Tope (2017) reported that water treatment is expensive in the rural areas and a major problem for the availability of potable water in the rural communities. SSF could be used effectively in rural areas for water purification because it is cheap, easy to operate, does not require electricity for its operation and could be fabricated from locally available materials (Yusuf et al., 2019). Langenbach et al. (2009) reported that SSF is a simple technology for drinking water purification and is effective in the removal of particles and pathogen from the water. SSF had been used for treating water for the past 200 years ago and remain as one of the appropriate methods for purifying water today. Granular Activated Carbon (GAC) and Powdered Activated Carbon (PAC) are commonly used for treating drinking water to adsorb chemicals and compounds that could cause odour, taste, colour and toxic to man (EPA, 2016). GAC or PAC surface is oleophilic (oil loving) which is opposite of hydrophilic (water loving). GAC has ability to remove physicochemical and organic compounds from contaminated water while sand medium traps pathogens from water. GAC adsorbs the contaminants onto the carbon surface where they are held by van der Waals forces. GAC an adsorbent agent and it uses the principle of adsorption to remove chemicals and some organic compounds from the contaminated water. GAC or $\mathrm{PAC}$ is an activated carbon and a substance or material that could be made from carbonaceous materials such as coconut shell, wood, rice husk, coal and other agricultural materials which is processed by heating in a furnace at a high temperature ranging from $450-900^{\circ} \mathrm{C}$ or prepared by using chemicals such as potassium hydroxide $(\mathrm{KOH})$, sodium hydroxide $(\mathrm{NaOH})$, zinc chloride $\left(\mathrm{ZnCl}_{2}\right)$, tetra oxo sulphate (vi) acid $\left(\mathrm{H}_{2} \mathrm{SO}_{4}\right)$ to GAC or PAC (Das et al., 2015). EPA (2016) stated that GAC could be used as filter medium or incorporate in the filter media of the SSF. A SSF could effectively remove some toxic chemicals and hazardous materials from the water (El-Harbawi et al., 2010). Basak (2003) reported that SSF could improve physicochemical and biological properties of water when water flows through it. The pollutants removal from the raw water and purification efficiency of the SSF depend on the filter depth, sand type, sand size and filtration rate (Abdudi, 2011). WHO (1996) pointed out that SSF could remove between 98 and $99 \%$ of the diseases causing pathogens which could prevent some diseases both in the rural and urban areas of Nigeria.

The water tank which supplies raw water to the filter chamber could be 1 to $1.5 \mathrm{~m}$ above the filter medium to provide the required pressure that would carry the water through the filter media. Visscher et al. (1987) recommended three layers of filter media mainly fine sand, coarse sand and gravel with a minimum depth of $60 \mathrm{~cm}$ of filter bed for purification of water by slow sand filter. Bagundol et al. (2013) reported that 30, 60 and 90 $\mathrm{cm}$ filter bed (sand) depths reduced the turbidity by $90 \%$ with highest percentage reduction by $90 \mathrm{~cm}$ depth and the three depths performed effectively in the removal of E. Coli from the water. The 
objectives of this study were to fabricate slow sand filter and determine the effect of granular activated carbon in slow sand filter on some physicochemical and bacteriological properties of well water.

Page | 3883

\section{Materials and Methods \\ Location of the study}

The research was conducted at the Department of Agricultural and Biosystems Engineering, University of Ilorin, Ilorin, Kwara State, Nigeria. Ilorin is located on latitude $8^{\circ} 30^{1} \mathrm{~N}$ and longitude $4^{\circ} 35^{1} \mathrm{E}, 340 \mathrm{~m}$ above the mean sea level and has about $1,300 \mathrm{~mm}$ annual rainfall.

\section{Description of the slow sand filter}

The SSF was constructed using locally available materials that are readily available in Ilorin, Kwara State, Nigeria. The filter chamber was constructed from 6 inches $(15.24 \mathrm{~cm}$ internal diameter and $16.50 \mathrm{~cm}$ external dimeter) and $110 \mathrm{~cm}$ long PVC pipe. The sand used in this study as the filter medium was freely running sand which was sieved through $0.25 \mathrm{~mm}$ and the gravel sieved through 10 $\mathrm{mm}$ and $14 \mathrm{~mm}$ sieves. The sand filter material was collected and soaked in water for 48 hours for softening and easy separation of foreign particles from the sand. The sand was thoroughly washed with tap water to remove organic matter, dead insects, colloids, some soluble minerals (salt) in water and then sun-dry for 4 days. Washing of the sand filter material is essential to have a clean filter material that is free from insects, organic matter, clay particles and some soluble minerals. The filter chamber of the PVC pipe was divided into two parts: the upper part ( $75 \mathrm{~cm}$ high PVC pipe) where the filter media were put to filter the raw water and its bottom was covered with $15.30 \mathrm{~cm}$ diameter PVC perforated with $2 \mathrm{~mm}$ holes. The lower part of the filter chamber ( $35 \mathrm{~cm}$ high PVC pipe) serves as the storage unit for the filtered water before it is collected to the outlet storage tank.
The gravel (grain size of $14 \mathrm{~mm}$ ) was put on the upper filter chamber from the bottom to a height of $6 \mathrm{~cm}$ and gravel of $10 \mathrm{~mm}$ grain size was put after the layer of $14 \mathrm{~mm}$ gravel to a height of $4 \mathrm{~cm}$. The gravel allows easy flow of filtered water after the sand medium from the upper filter chamber to the lower filter chamber which is the storage chamber unit for the filtered water. Water flows from the raw water storage tank (50 litres capacity) through $12.7 \mathrm{~mm}$ ( 0.5 inch) PVC pipe to the filter chamber. The top of raw water storage tank is 100 $\mathrm{cm}$ above the filter bed so that it could provide the needed pressure that would move the water through the filter bed. The filtered water is drained to the water outlet storage tank through a $12.7 \mathrm{~mm}$ PVC pipe connected to the lower part of filter chamber at $5 \mathrm{~cm}$ above the base of the lower filter chamber. The inflow and outflow of water has tap for regulating the discharge of water from the water storage tank into the filter chamber and from the outlet. The water storage tank and the filter chamber rest on wooden stood. The fabricated SSF has a capacity of 35 litres/h and the exploded view of the SSF is shown in Figure 1 and orthographic view of the $\mathrm{SSF}_{1}$ is shown in Figure 2. The total cost of the SSF between May and June, 2019 using readily available materials in Ilorin was twenty-six thousand fifty naira $(\mathrm{N} 26,150)$ which is equivalent to 72.64 U.S. Dollar (USD 72.64) as shown in Table 1 of the Bill of Engineering Measurements and Evaluations.

\section{Preparation of the granular activated carbon from shea butter tree}

The GAC was produced from shea butter tree. The shea butter tree (fresh/wet) was firstly burnt in an open space to obtain charcoal (not burnt to ash but charcoal). The charcoal was broken into smaller pieces and immersed in a solution of $\mathrm{CaCl}_{2}$ for 24 hours to impregnate it, the charcoal was removed and put in a crucible for 1 hour at room temperature. The charcoal was put inside a furnace and heated for 20 minutes at temperature of $450^{\circ} \mathrm{C}$ to form the GAC as shown in Figure 3. The GAC 
was removed from the furnace, washed with distilled water to reduce the $\mathrm{pH}$ level and then oven dry for 2 hours at temperature of $105^{\circ} \mathrm{C}$. The GAC was sieved through $10 \mathrm{~mm}$ and $14 \mathrm{~mm}$ sieves to have two different particle grain sizes.

Table 1: Bill of Engineering Measurement and Evaluation for the SSF as at May - June, 2019

\begin{tabular}{|c|c|c|c|c|c|}
\hline $\mathrm{S} / \mathrm{N}$ & Item & Description & Quantity & Rate (N) & $\begin{array}{l}\text { Amount } \\
\text { (N) }\end{array}$ \\
\hline 1 & $\begin{array}{l}50 \text { litres } \\
\text { plastic bucket }\end{array}$ & $\begin{array}{l}\text { Storage tank } \\
\text { for raw } \\
\text { water } \\
\text { container }\end{array}$ & 1 & 1,500 & 1,500 \\
\hline 2 & $\begin{array}{l}20 \text { litres } \\
\text { Plastic bucket }\end{array}$ & $\begin{array}{l}\text { Filtered } \\
\text { water } \\
\text { container }\end{array}$ & 1 & 700 & 700 \\
\hline 3 & $\begin{array}{l}\text { PVC Pipe (6 } \\
\text { inch) }\end{array}$ & $\begin{array}{l}\text { Outlet raw } \\
\text { water pipe }\end{array}$ & 1 & 5,000 & 5,000 \\
\hline 4 & $\begin{array}{l}\text { PVC Pipe (1/2 } \\
\text { inch) }\end{array}$ & $\begin{array}{l}\text { Raw water } \\
\text { outlet }\end{array}$ & 1 & 400 & 400 \\
\hline 5 & $\begin{array}{l}\text { PVC Pipe (3/4 } \\
\text { inch) }\end{array}$ & $\begin{array}{l}\text { Filtered } \\
\text { water outlet }\end{array}$ & 1 & 450 & 450 \\
\hline 4 & $\begin{array}{l}\text { Plastic control } \\
\text { tap (1/2 inch) }\end{array}$ & $\begin{array}{l}\text { Raw water } \\
\text { outlet }\end{array}$ & 1 & 400 & 400 \\
\hline 5 & $\begin{array}{l}\text { Plastic Control } \\
\text { tap (3/4 inch) }\end{array}$ & $\begin{array}{l}\text { Filtered } \\
\text { water outlet }\end{array}$ & 1 & 500 & 500 \\
\hline 6 & Wooden stand & $\begin{array}{l}\text { Stood for } \\
\text { storage tank }\end{array}$ & 1 & 3,500 & 3,500 \\
\hline 7 & $\begin{array}{l}\text { PVC Pipe (1/2 } \\
\text { inch) }\end{array}$ & $\begin{array}{l}\text { Outlet clean } \\
\text { water pipe }\end{array}$ & 1 & 500 & 500 \\
\hline 8 & $\begin{array}{l}\text { Granular } \\
\text { activated } \\
\text { carbon }\end{array}$ & $\begin{array}{l}10 \mathrm{~mm} \text { size } \\
\text { (12 litres), } \\
14 \mathrm{~mm} \text { size } \\
\text { (4 litres) }\end{array}$ & $\begin{array}{l}16 \text { litres } \\
\text { capacity }\end{array}$ & 3,700 & 3,700 \\
\hline 9 & Silicon gum & $\begin{array}{l}\text { Sealant gum } \\
\text { for pipe } \\
\text { connection }\end{array}$ & - & 700 & 700 \\
\hline 10 & $\begin{array}{l}\text { Back-nut } \\
\text { fitting (3/4 } \\
\text { inch) }\end{array}$ & $\begin{array}{l}\text { Draining of } \\
\text { dirty water }\end{array}$ & 1 & 500 & 500 \\
\hline 11 & Tigre elbow & $\begin{array}{l}\text { Elbow join } \\
\text { connection }\end{array}$ & 1 & 10 & 100 \\
\hline 12 & $\begin{array}{l}\text { Fine sand } \\
(0.25 \mathrm{~mm}) \text { and } \\
\text { gravel }(11 \mathrm{~mm} \\
\text { and } 14 \mathrm{~mm})\end{array}$ & $\begin{array}{l}30 \text { litres } \\
\text { capacity for } \\
\text { the } 4 \text { slow } \\
\text { sand filters }\end{array}$ & $\begin{array}{l}\text { Obtained } \\
\text { freely }\end{array}$ & $\begin{array}{l}\text { Obtained } \\
\text { freely }\end{array}$ & 0 \\
\hline 13 & $\begin{array}{l}\text { Transportation } \\
\text { for materials }\end{array}$ & & & & 2,700 \\
\hline \multirow[t]{2}{*}{14} & Labour cost & $\begin{array}{l}\text { Pipe fittings } \\
\text { and Filter } \\
\text { chamber } \\
\text { construction }\end{array}$ & 1 & 1 & 5,500 \\
\hline & Total & & & $\begin{array}{r}\mathrm{N} 26,150 \\
\text { USD72.64 }\end{array}$ & $=$ \\
\hline
\end{tabular}

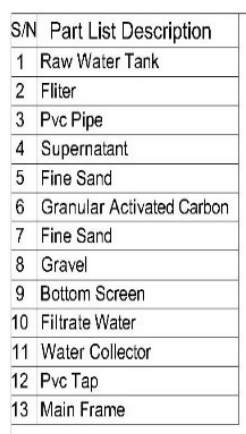

Figure 1: Exploded view of the slow sand filter

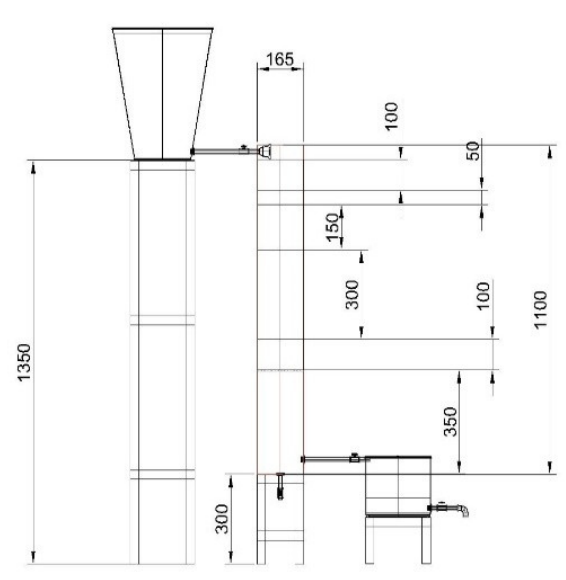

All dimensions in (mm)

Figure 2: Orthographic view of the first $\mathrm{SSF}_{1}$

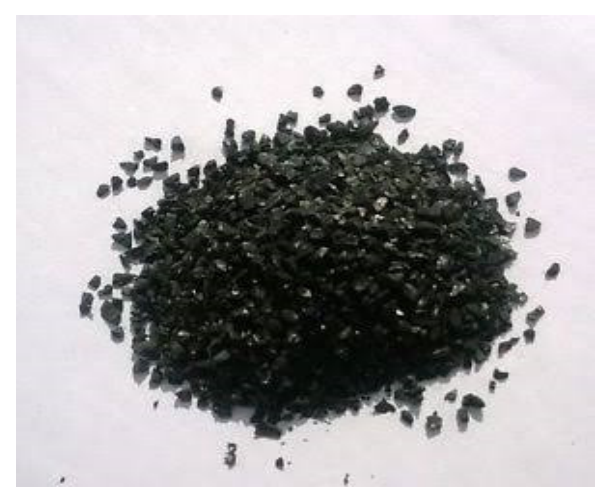

Figure 3: Granular activated carbon 


\section{Operating principles and maintenance of the slow sand filter}

Some quantity of water about 25 litres to be filtered was poured into the raw storage tank of the filter Page | 3885 and the control tap was opened for the water to flow into the filter chamber. It takes about $5-10$ minutes for the raw water to flow through the filter bed and to get clean water from the outlet of the filter. When the outlet control tap was opened, clean water would flow through the outlet and the water is collected from the outlet. The SSF is very simple to operate and it doesn't need electricity for its operation. The filter was kept moist for 21 days for biofilm layer (schmutzdecke) to form which is effective in trapping bacteria from the contaminated water.

Maintenance of the slow sand filter is required after the SSF has been used continuously over a long period of for filtering water and could not allow flow water through it due to blockage of the pores of the filter bed by accumulation of particles. Maintenance is done by the removal of about $5 \mathrm{~cm}$ layer of the fine sand from the top of the filter sand material and replace with new clean fine sand.

\section{Performance evaluation of the slow sand filter and water qualities analysis}

The capacity of the SSF was evaluated by determining the volume of water it could filter per time using Equation (1). The performance evaluation of the SSF was carried out using well water from three different sources. The chemicals analyzed in the water were Cadmium, Lead, Manganese, Copper, Iron and Calcium. Clean and sterilized plastic bottles were used to collect water samples for the analysis. Physico-chemical and bacteriological properties of the water were determined using the standard methods given by AOAC (2000).

$$
Q=\frac{V}{T}
$$

where Q is the discharge or capacity of the slow sand filter (litre/h), $\mathrm{V}$ is the volume of water collected from outlet (litre) and $\mathrm{T}$ is the time taken to obtain the volume of the water (h).

\section{Computation of paired t-test statistical analysis}

A paired t-test statistical analysis was used in this study to determine if the effect of GAC in the SSF was statistically significant or not on the purification of the water. The difference between the two mean of the results was computed and used to determine the standard deviation, standard error and t-test value using Equations (2), (3a) or (3b), (4) and (5), respectively as given by Montgomery (1998). The data used for the computation of the paired t-test as an illustration in this study were extracted from Table 3 and presented in Table 2. The calculated values of the t-test and that of table values of the t-test were compared.

$$
\begin{gathered}
\bar{d}=\frac{\sum d}{n} \\
\delta=\sqrt{\frac{\sum d^{2}-n(\bar{d})^{2}}{n-1}} \\
\delta=\sqrt{\frac{\sum(d-\bar{d})^{2}}{n-1}} \\
\delta_{E r}=\frac{\delta}{\sqrt{n}} \\
t_{c a l}=\frac{\bar{d}}{\delta_{E r}}
\end{gathered}
$$

Where $\mathrm{d}$ is the mean of the difference from the data $\mathrm{x}_{1}$ and $\mathrm{x}_{2}, \Sigma \mathrm{d}$ is the summation of $\mathrm{d}, \mathrm{n}$ is the number of observations, $\delta$ is the standard deviation, $\delta_{\mathrm{Er}}$ is the standard error and $t_{\text {cal }}$ is the calculated value of t at $\alpha=5 \%$ but $2.5 \%$ for paired t-test $(\alpha=0.05 / 2=$ $0.025)$. 
Table 2: Data for physicochemical and bacteriological properties of water before and after filtration by the slow sand filter with GAC of $10 \mathrm{~mm}$ grain size and $25 \mathrm{~cm}$ depth

\begin{tabular}{|c|c|c|c|c|c|}
\hline \multirow[t]{11}{*}{ Page | 3886} & Parameter & $\begin{array}{l}\text { Raw } \\
\text { water } \\
\left(\mathrm{W}_{1 \mathrm{r}}\right)\end{array}$ & $\begin{array}{l}\text { Filtered } \\
\text { water } \\
\mathrm{SSF}_{B} \\
\left(\mathrm{~W}_{1 \mathrm{ff}}\right)\end{array}$ & $\begin{array}{l}\mathrm{d}=\mathrm{W}_{1 \mathrm{r}} \\
\mathrm{W}_{1 \mathrm{f}}\end{array}$ & $d^{2}$ \\
\hline & $\overline{\mathrm{Pb}^{2+}(\mathrm{mg} / \mathrm{l})}$ & 0.1010 & 0.0002 & 0.1008 & 0.0102 \\
\hline & $\mathrm{Mn}^{2+}(\mathrm{mg} / \mathrm{l})$ & 1.2000 & 0.0200 & 1.1800 & 1.3924 \\
\hline & $\mathrm{Cu}^{2+}(\mathrm{mg} / \mathrm{l})$ & 0.0700 & 0.0400 & 0.0300 & 0.0009 \\
\hline & $\mathrm{Ca}^{2+}(\mathrm{mg} / \mathrm{l})$ & 0.1700 & 0.7800 & $-0.6100 *$ & 0.3721 \\
\hline & $\mathrm{Fe}^{3+}(\mathrm{mg} / \mathrm{l})$ & 0.1000 & 0.0100 & 0.0900 & 0.0081 \\
\hline & $\mathrm{pH}$ & 6.5000 & 7.2000 & $-0.0700^{*}$ & 0.0049 \\
\hline & Turbidity & 2.3000 & 0.0400 & 2.2600 & 5.1075 \\
\hline & FVC & 2.4000 & 1.0268 & 2.3732 & 5.6321 \\
\hline & FCC & 1.8000 & 1.1000 & 0.7000 & 0.0049 \\
\hline & & $\mathbf{n}=\mathbf{9}$ & & $\sum d=7.414$ & $\begin{array}{l}\sum d^{2}= \\
13.0182\end{array}$ \\
\hline
\end{tabular}

* = The negative in the value of deviation (d) was ignored and used as positive in this study because the increment is a positive effect in this study for $\mathrm{pH}$ and $\mathrm{Ca}^{2+}$

$$
\begin{aligned}
& \bar{d}=\frac{7.414}{9}=0.824 \\
& \delta=\sqrt{\frac{13.0182-9(0.824)^{2}}{9-1}}=0.9292 \\
& \delta_{E r}=\frac{0.9292}{\sqrt{9}}=0.3097 \\
& t_{c a l}=\frac{0.824}{0.3097}=2.661
\end{aligned}
$$

\section{Results and Discussion}

The fabricated SSF in this study shown in Figure 4 has a capacity of producing 35 litres/h of clean water that is safe for drinking without causing diseases to man from the well water. Well water from 3 sources that are used for drinking were used in this study for the performance evaluation of the SSF having GAC with different particle sizes and depths. The results of varying the grain size of the GAC on physical, chemical and bacteriological properties of the water obtained from the filtered and non-filtered water using SSF with $10 \mathrm{~mm}$ and $14 \mathrm{~mm}$ GAC particle sizes and $15 \mathrm{~cm}$ depth were shown in Table 3. The results of varying the depth of the GAC on physical, chemical and bacteriological properties of the water obtained from the filtered and non-filtered water using SSF with $15 \mathrm{~cm}$ and $25 \mathrm{~cm}$ depths of GAC and particle size of $10 \mathrm{~mm}$ was shown in Table 4 . Table 5 shows the percentage reduction (removal) of the contaminants in the filtered water compared with the non-filtered water before the filtration using SSF.

From Table 5, SSF reduced Lead, Manganese, Copper, Iron, Turbidity and Total coliform counts of the filtered water by $91.35-99.88 \%, 90.00$ $98.33 \%, 42.00-100.00 \%, 46.67-100.00 \%, 13.04-$ $99.15 \%$ and $16.67-57.69 \%$, respectively when compared with raw water. The SSF was effective in the removal of heavy metals like Lead, Manganese, Copper that could cause cancer and other diseases to man after prolong consumption of the water. This was in agreement with the conclusion from the study by Meena et al. (2010) that the chemically treated GAC is a good adsorbent agent and it could remove nearly $100 \%$ heavy metals from the contaminated water. The SSF reduced Lead, Manganese and Copper to permissible limits of World Health Organisation (WHO, 1996). The filter with different grain sizes of $10 \mathrm{~mm}$ and $14 \mathrm{~mm}$ with depths of $15 \mathrm{~cm}$ and $25 \mathrm{~cm}$ had significant effect on the reduction of Iron and Turbidity, Lead, Manganese, Copper and Total coliform counts. The 
GAC in SSF had significant effect on water purification with calculated values of t-test varied from 2.438 to 3.236 while the table value of $\alpha$ at $\alpha$ $\leq 0.05$ ( $\alpha \leq 0.025$ for paired t-test) was 2.306 as shown in Table 6 .

The SSF increased $\mathrm{pH}$ and Calcium by 7.14$27.71 \%$ and $83.65-98.21 \%$, respectively. This increased in Calcium content is a positive effect to provide alternative source of Calcium for man in some developing countries where balanced diet is not available. WHO (2005) reported that Calcium in drinking water is very important as a source of Calcium in human body which is needed for bone development, regulation of many enzymes, hormonal responses and blood clotting. SSF with GAC grain size $10 \mathrm{~mm}$ and $25 \mathrm{~cm}$ depths GAC reduced the pollutants better than the other two filters having grain size $10 \mathrm{~mm}$ but with $15 \mathrm{~cm}$ depths and SSF with grain size $14 \mathrm{~mm}$ and $15 \mathrm{~cm}$ depth of GAC. This means that the thickness (depth) of GAC increased the time which the raw water spent in GAC and increased the efficiency of the SSF for the removal of chemicals from the water. The SSF reduced the turbidity from $13.04-$ $99.15 \%$ in this study and this was in agreement with the study of Bagundol et al. (2013) that slow sand filter reduced turbidity of well water by $99 \%$ when depths of filter medium varied from 30-90 $\mathrm{cm}$.

All the three sources of the well water $\left(\mathrm{W}_{1}, \mathrm{~W}_{2}\right.$ and $\mathrm{W}_{3}$ ) did not contain feacal coliform counts (FCC) which could be an indication of presence of E. Coli in the water that could cause diseases to man. The bacteriological analysis revealed total viable counts and total colony but the bacteriological parameters are not harmful to man though the values in the water above permissible limits of WHO (1996).
Bagundol et al. (2013) also pointed out that the efficiency of E. Coli removal by SSF depends on the depth of the sand filter medium, biofilm layer and flow rate of the water through the filter which means that SSF could not totally remove E. Coli by $100 \%$ especially water in areas with high contamination of E. coli (pathogens). The GAC in the SSF was effective in the removal heavy metals by $42.00-100 \%$ but it increased the calcium by $83.65-98.21 \%$ and $\mathrm{pH}$ values of the water ranged from 7.14 - 24.00 which were within the permissible limits of WHO (1996) as shown in Table 5. All the physical and chemical properties of water that were above the limits before filtration were reduced to permissible limits of WHO (1996).

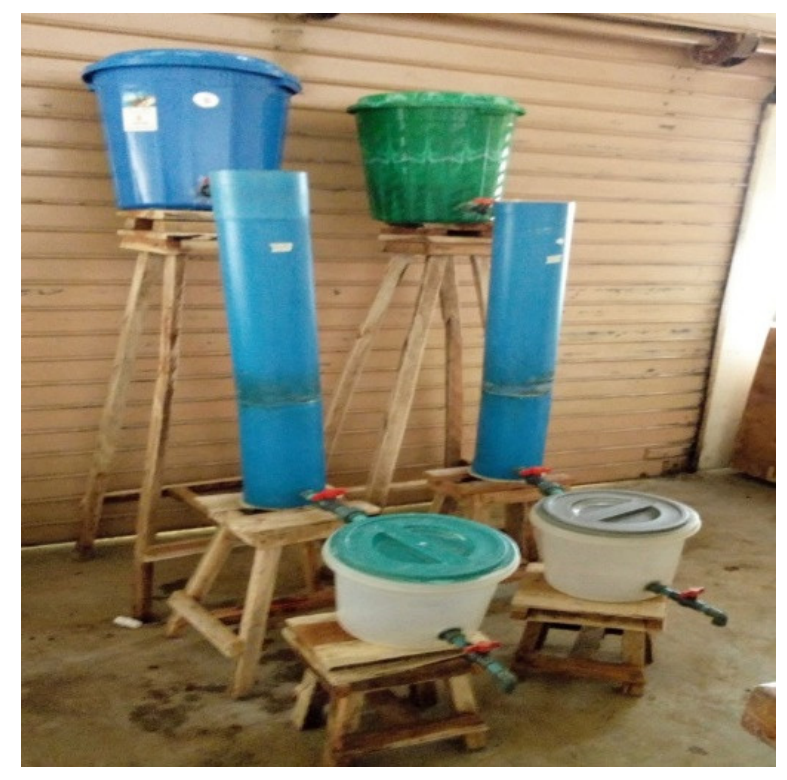

Figure 4: Pictorial view of the slow sand filters 
Table 1: Physicochemical and bacteriological properties of water after passing through the

SSF with $10 \mathrm{~mm}$ and $14 \mathrm{~mm}$ particle sizes and $15 \mathrm{~cm}$ depth

$\begin{array}{lcccc}\begin{array}{c}\text { Property } \\ \text { analyzed }\end{array} & \text { Raw water } & \mathrm{SSF}_{1} \text { with size } 10 \mathrm{~mm} \text { GAC } & \mathrm{SSF}_{2} \text { with size } 14 \mathrm{~mm} \text { GAC } & \text { WHO } \\ \text { and } 15 \mathrm{~cm} \text { depth } & & \text { and } 15 \mathrm{~cm} \text { depth } & \text { limits }\end{array}$

\begin{tabular}{|c|c|c|c|c|c|c|c|c|c|c|}
\hline & $\mathrm{W}_{1}$ & $\mathrm{~W}_{2}$ & $\mathrm{~W}_{3}$ & $\mathrm{~W}_{1}$ & $\mathrm{~W}_{2}$ & $\mathrm{~W}_{3}$ & $\mathrm{~W}_{1}$ & $\mathrm{~W}_{2}$ & $\mathrm{~W}_{3}$ & \\
\hline Page | ${ }^{3888} \mathrm{Cd}^{2+}(\mathrm{mg} / \mathrm{l})$ & ND & ND & ND & ND & ND & ND & ND & ND & ND & 0.0030 \\
\hline $\mathrm{Pb}^{2+}(\mathrm{mg} / \mathrm{l})$ & 0.1010 & 0.1040 & 0.1030 & 0.0010 & 0.0040 & 0.0020 & 0.0009 & 0.0090 & 0.0005 & 0.0100 \\
\hline $\mathrm{Mn}^{2+}(\mathrm{mg} / \mathrm{l})$ & 1.2000 & 1.9000 & 1.4000 & 0.0800 & 0.1000 & 0.1000 & 0.1100 & 0.1300 & 0.1400 & 0.2000 \\
\hline $\mathrm{Cu}^{2+}(\mathrm{mg} / \mathrm{l})$ & 0.0700 & 0.0300 & 0.0400 & 0.0400 & 0.0000 & 0.0000 & 0.0600 & 0.0000 & 0.0070 & 1.0000 \\
\hline $\mathrm{Ca}^{2+}(\mathrm{mg} / \mathrm{l})$ & 0.1700 & 0.0500 & 0.1100 & 1.2600 & 2.9300 & 1.9000 & 1.4400 & 2.2000 & 1.2800 & 200.00 \\
\hline $\mathrm{Fe}^{3+}(\mathrm{mg} / \mathrm{l})$ & 0.1000 & 0.1500 & 0.1200 & 0.0100 & 0.0500 & 0.0300 & 0.0300 & 0.0800 & 0.0200 & 0.3000 \\
\hline $\mathrm{pH}$ & 6.5000 & 5.7000 & 6.0000 & 7.0000 & 6.8000 & 6.9000 & 7.0000 & 6.9000 & 8.3000 & $6.5-8.5$ \\
\hline $\begin{array}{c}\text { Turbidity } \\
\text { (NTU) }\end{array}$ & 2.3000 & 6.6800 & 5.1000 & 1.7000 & 3.1800 & 2.7000 & 2.0000 & 3.7000 & 3.0800 & 5.0000 \\
\hline $\begin{array}{l}\text { TVC x } 10^{4} \\
(\mathrm{cfu} / 100 \mathrm{ml})\end{array}$ & 2.400 & 3.000 & 2.700 & 1.400 & 1.700 & 1.500 & 1.900 & 2.300 & 1.800 & $\begin{array}{c}10.00 \mathrm{x} \\
10^{-4}\end{array}$ \\
\hline $\begin{array}{c}\mathrm{TCC} \times 10^{4} \\
(\mathrm{cfu} / 100 \mathrm{ml})\end{array}$ & 1.800 & 2.600 & 2.100 & 1.000 & 1.200 & 1.000 & 1.500 & 1.600 & 1.300 & $\begin{array}{c}10.00 \mathrm{x} \\
10^{-4}\end{array}$ \\
\hline $\begin{array}{c}\text { FCC } \\
\text { (cfu/100ml) }\end{array}$ & 0.0000 & 0.0000 & 0.0000 & 0.0000 & 0.0000 & 0.0000 & 0.0000 & 0.0000 & 0.0000 & 0.0000 \\
\hline
\end{tabular}

Table 2: Physicochemical and bacteriological parameters of water after passing through the SSF with varying depths $(15$ and $25 \mathrm{~cm})$ of GAC and particle size $10 \mathrm{~mm}$

\begin{tabular}{ccccccccccc}
\hline $\begin{array}{c}\text { Property } \\
\text { analyzed }\end{array}$ & \multicolumn{3}{c}{ Raw water } & \multicolumn{9}{c}{$\mathrm{SSF}_{\mathrm{A}}$ with $10 \mathrm{~mm}$ GAC and } & \multicolumn{3}{c}{$\mathrm{SSF}$ with $10 \mathrm{~mm}$ GAC and } & WHO \\
& $\mathrm{W}_{1}$ & $\mathrm{~W}_{2}$ & $\mathrm{~W}_{3}$ & $\mathrm{~W}_{1}$ & $\mathrm{~W}_{2}$ & $\mathrm{~W}_{3}$ & $\mathrm{~W}_{1}$ & $\mathrm{~W}_{2}$ & $\mathrm{~W}_{3}$ & \\
\hline $\mathrm{Cd}^{2+}(\mathrm{mg} / \mathrm{l})$ & $\mathrm{ND}$ & $\mathrm{ND}$ & $\mathrm{ND}$ & $\mathrm{ND}$ & $\mathrm{ND}$ & $\mathrm{ND}$ & $\mathrm{ND}$ & $\mathrm{ND}$ & $\mathrm{ND}$ & 0.0030 \\
$\mathrm{~Pb}^{2+}(\mathrm{mg} / \mathrm{l})$ & 0.1010 & 0.1040 & 0.1030 & 0.0010 & 0.0040 & 0.0020 & 0.0002 & 0.0006 & 0.0004 & 0.0100 \\
$\mathrm{Mn}^{2+}(\mathrm{mg} / \mathrm{l})$ & 1.2000 & 1.900 & 1.4000 & 0.0800 & 0.1000 & 01000 & 0.0200 & 0.0400 & 0.1000 & 0.2000 \\
$\mathrm{Cu}^{2+}(\mathrm{mg} / \mathrm{l})$ & 0.0700 & 0.0300 & 0.0400 & 0.0400 & 0.0000 & 0.0000 & 0.0400 & 0.0000 & 0.0000 & 1.0000 \\
$\mathrm{Ca}^{2+}(\mathrm{mg} / \mathrm{l})$ & 0.1700 & 0.0500 & 0.1100 & 1.2600 & 2.9300 & 1.9000 & 0.7800 & 1.6400 & 1.0000 & 200.00 \\
$\mathrm{Fe}^{3+}(\mathrm{mg} / \mathrm{l})$ & 0.1000 & 0.1500 & 0.1200 & 0.0100 & 0.0500 & 0.0300 & 0.0100 & 0.0200 & 0.0000 & 0.3000 \\
$\mathrm{pH}$ & 6.5000 & 5.7000 & 6.0000 & 7.0000 & 6.8000 & 6.9000 & 7.2000 & 7.5000 & 7.2000 & $6.5-8.5$ \\
$\begin{array}{c}\mathrm{Turbidity} \\
(\mathrm{NTU})\end{array}$ & 2.3000 & 6.6800 & 5.1000 & 1.7000 & 3.1800 & 2.7000 & 0.0400 & 2.0100 & 0.0300 & 5.0000 \\
$\begin{array}{c}\mathrm{TVC} \\
(\mathrm{cfu} / 100 \mathrm{ml})\end{array}$ & 2.4000 & 3.0000 & 2.7000 & 1.4000 & 1.7000 & 1.5000 & 1.1000 & 1.3000 & 1.3000 & 10.00 \\
$\begin{array}{c}\mathrm{TCC} \\
(\mathrm{cfu} / 100 \mathrm{ml})\end{array}$ & 1.8000 & 2.6000 & 2.1000 & 1.0000 & 1.2000 & 1.0000 & 1.0000 & 1.1000 & 1.0000 & 10.00 \\
$\begin{array}{c}\mathrm{FCC} \\
(\mathrm{cfu} / 100 \mathrm{ml})\end{array}$ & $\mathrm{ND}$ & $\mathrm{ND}$ & $\mathrm{ND}$ & $\mathrm{ND}$ & $\mathrm{ND}$ & $\mathrm{ND}$ & $\mathrm{ND}$ & $\mathrm{ND}$ & $\mathrm{ND}$ & 0.00 \\
\hline
\end{tabular}

$\mathrm{SSF}_{\mathrm{A}}=$ First slow sand filter, $\mathrm{SSF}_{\mathrm{B}}=$ Second slow sand filter, $\mathrm{W}_{1}, \mathrm{~W}_{2}$ and $\mathrm{W}_{3}$ were defined in Table 3 
Table 3: Percentage reduction of Physicochemical and bacteriological parameters of water after passing through the slow sand filter compared to non-filtered water

\begin{tabular}{|c|c|c|c|c|c|c|c|c|c|}
\hline $\begin{array}{l}\text { Property } \\
\text { analyzed }\end{array}$ & $\begin{array}{l}\text { Reduc } \\
10 \mathrm{~mm}\end{array}$ & $\begin{array}{l}(\%) \text { fo } \\
\mathrm{C} \text { and } 15\end{array}$ & $\begin{array}{l}\text { SSF with } \\
\text { depth }\end{array}$ & $\begin{array}{l}\text { Reduc } \\
\mathrm{mm} \mathrm{G}\end{array}$ & $\begin{array}{l}\text { (\%) for } \\
\text { and } 15 \mathrm{cr}\end{array}$ & $\begin{array}{l}\text { F with } 14 \\
\text { depth }\end{array}$ & $\begin{array}{l}\text { Reduc } \\
\mathrm{mm} \mathrm{G}\end{array}$ & $\begin{array}{l}(\%) \text { for } \\
\text { and } 25 \mathrm{c}\end{array}$ & $\begin{array}{l}\text { F with } 10 \\
\text { lepth }\end{array}$ \\
\hline 39 & $\mathrm{~W}_{1}$ & $\mathrm{~W}_{2}$ & $\mathrm{~W}_{3}$ & $\mathrm{~W}_{1}$ & $\mathrm{~W}_{2}$ & $\mathrm{~W}_{3}$ & $\mathrm{~W}_{1}$ & $\mathrm{~W}_{2}$ & $\mathrm{~W}_{3}$ \\
\hline $\mathrm{Cd}^{2+}(\mathrm{mg} / \mathrm{l})$ & ND & ND & ND & ND & ND & ND & ND & ND & ND \\
\hline $\mathrm{Pb}^{2+}(\mathrm{mg} / \mathrm{l})$ & 99.01 & 96.15 & 96.02 & 99.11 & 91.35 & 99.51 & 99.61 & 99.80 & 99.42 \\
\hline $\mathrm{Mn}^{2+}(\mathrm{mg} / \mathrm{l})$ & 93.33 & 94.74 & 92.86 & 90.83 & 93.16 & 90.00 & 98.33 & 97.89 & 92.86 \\
\hline $\mathrm{Cu}^{2+}(\mathrm{mg} / \mathrm{l})$ & 42.86 & 100.00 & 100.00 & 42.29 & 100.00 & 82.50 & 42.00 & 100.00 & 100.00 \\
\hline $\mathrm{Fe}^{3+}(\mathrm{mg} / \mathrm{l})$ & 90.00 & 66.67 & 75.00 & 70.00 & 46.67 & 83.33 & 90.00 & 86.67 & 100.00 \\
\hline $\mathrm{Ca}^{2+}(\mathrm{mg} / \mathrm{l})$ & 86.51 & 98.21 & 94.21 & 83.65 & 97.73 & 91.41 & 83.68 & 96.95 & 89.09 \\
\hline Increment & & & & & & & & & \\
\hline $\mathrm{pH}$ Increment & 7.14 & 16.18 & 13.04 & 7.70 & 17.39 & 27.71 & 16.67 & 24.00 & 9.72 \\
\hline $\begin{array}{l}\text { Turbidity } \\
\text { (NTU) }\end{array}$ & 13.04 & 44.61 & 98.43 & 26.09 & 52.40 & 47.06 & 98.26 & 99.85 & 99.41 \\
\hline $\begin{array}{l}\text { TVC } \\
(\mathrm{cfu} / 100 \mathrm{ml})\end{array}$ & 41.67 & 43.33 & 44.44 & 20.83 & 23.33 & 33.33 & 54.17 & 63.33 & 51.85 \\
\hline $\begin{array}{l}\text { TCC } \\
(\mathrm{cfu} / 100 \mathrm{ml})\end{array}$ & 52.38 & 53.85 & 52.38 & 16.67 & 38.46 & 38.10 & 44.44 & 57.69 & 52.28 \\
\hline
\end{tabular}

Table 6: Results of the statistical analysis of the paired t-test for the effect of GAC on water purification using filtered and non-filtered water, $\mathrm{SSF}_{1}$ and $\mathrm{SSF}_{2}$

\begin{tabular}{cccccc}
\hline Well & $\begin{array}{c}\text { Grain size } \\
\text { GAC }(\mathrm{mm})\end{array}$ & $\begin{array}{c}\text { Depth of GAC } \\
(\mathrm{cm})\end{array}$ & $\begin{array}{c}\text { Degree of } \\
\text { freedom }\end{array}$ & $\begin{array}{c}\text { Calculated } \\
\text { value of } \mathrm{t}\end{array}$ & $\begin{array}{c}\text { Table value of } \\
\text { at } \alpha \leq 0.025\end{array}$ \\
\hline $\mathrm{W}_{1}$ & 10 & 25 & 8 & $2.661^{\mathrm{S}}$ & 2.306 \\
$\mathrm{~W}_{2}$ & 10 & 25 & 8 & $3.125^{\mathrm{S}}$ & 2.306 \\
$\mathrm{~W}_{3}$ & 10 & 25 & 8 & $2.438^{\mathrm{S}}$ & 2.306 \\
$\mathrm{~W}_{1}$ & 14 & 15 & 8 & $2.644^{\mathrm{S}}$ & 2.306 \\
$\mathrm{~W}_{2}$ & 14 & 15 & 8 & $3.236^{\mathrm{S}}$ & 2.306 \\
$\mathrm{~W}_{3}$ & 14 & 15 & 8 & $3.024^{\mathrm{S}}$ & 2.306 \\
$\mathrm{~W}_{1}$ & $10 \& 14$ & $15, \mathrm{SSF}_{1 \& 2}$ & 8 & $2.460^{\mathrm{S}}$ & 2.306 \\
$\mathrm{~W}_{1}$ & $10, \mathrm{SSF}_{1 \& B}$ & $15, \& 25$ & 8 & $1.676^{\mathrm{NS}}$ & 2.306
\end{tabular}

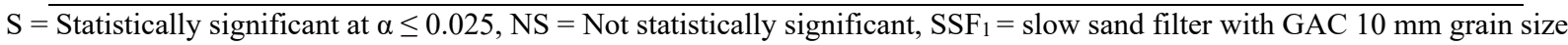
and depth $15, \mathrm{SSF}_{2}=$ slow sand filter with GAC $14 \mathrm{~mm}$ grain size and depth 15 while $\mathrm{SSF}_{\mathrm{B}}=$ slow sand filter with GAC grain size $10 \mathrm{~mm}$ and $25 \mathrm{~cm}$ depth, $\mathrm{W}_{1}, \mathrm{~W}_{2}$ and $\mathrm{W}_{3}$ were defined in Table 3. 


\section{Conclusions}

SSF was fabricated using readily available materials in the study area mainly PVC pipe, plastic bucket, freely running sand and granular Page | 3890 activated carbon. The SSF reduced heavy metals such as Lead, Manganese and Copper in the raw water which could cause cancer to man after prolong consumption by $42.29-99.81 \%$. It also reduced turbidity and total colony counts by 13.04 - $99.85 \%$ and 16.67 - 57.69\%, respectively. The $\mathrm{SSF}$ is recommended for purification of well water having heavy metals and organic compounds both in the rural and urban areas.

\section{References}

Abudi, Z. N. (2011). The effect of sand filter characteristics on removal efficiency of organic matter from grey water. AlQadisiya Journal for Engineering Sciences, 4 (2):143-155.

Ankidawa, B. A. and Tope, A. A. (2017). Design of Slow Sand Filter Technology for Rural Water Treatment in Girei, Adamawa State, North Eastern Nigeria, Asian Journal of Environment and Ecology, 3 (3): 1-7.

AOAC (2000). Official Methods of Analysis of the Association of Official Analytical Chemists 15th Edition, Arlington, Virginia, USA.

Ashbolt N. J. (2004). Microbial contamination of drinking water and disease outcomes in developing regions. Toxicology, 198 (1): 229-38.

Bagundol, T. B., Awa, A. L. and Enguito, M. R. C. (2013). Efficiency of Slow Sand Filter in Purifying Well Water. Journal of Multidisciplinary Studies, 2 (1): 86-102.

Basak, N. N. (2003). Environmental Engineering, Tata McGraw-Hill Publishing Company Ltd, New Delhi: 90 - 98.
EL-harbawi, M., Sabidi, A. A., Kamarudin, E, Abdhamid, A. Harun, S., Nazlan, A. and Xiyi, C. (2010). Design of a portable dual purposes water filter system, Journal of Engineering Science and Technology (JESTECH), 5 (2): 165 - 175.

EPA (1995). Water treatment manuals filtration. Environmental Protection Agency, Ireland: 1-80.

Fernandez, L. G. and Olalla, H. Y. (2000). Toxicity and bioaccumulation of lead and cadmium in marine protozoan communities. Ecotoxicology and Environmental Safety: 266-276.

Hammer, M. J. and Hammer, M. J. (2012). Water and wastewater technology, $7^{\text {th }}$ Edition, PHI Learning Private Ltd, New Delhi: 40 -50 .

Langenbach, K., Kuschk, P., Horn, H. and Kastner, M. (2009). Slow sand filtration of secondary clarifier effluent for wastewater reuse. Environmental Science and Technology, 43 (15?): 5896-5901

Meena, A. K.., Rajagupal, C., Kiran and Mishra, G. K. (2010). Removal of heavy metal ions from aqueous solution using chemically $\left(\mathrm{Na}_{2} \mathrm{~S}\right)$ treated granular activated carbon as an adsorbent. Journal of Scientific and Industrial Research, 69: 449-453.

Montgomery, D. C., Runger, G. C., Hubele, N. F (1998). Engineering statistics. John Wiley and Sons, Inc, New York: 135-248.

Visscher, J. T., Paramasivam, R., Raman, A. and Heijnen, H. A. (1987). Slow sand filtration for community water supply - planning, design, construction, operation and maintenance, Technical Paper Series 24, June 1987, International Reference Centre (IRC) for Community Water Supply and Sanitation, Netherlands. 
WHO (1996). Guidelines for Drinking-Water Quality-Health Criteria and other Supporting Information, Second Edition, World Health Organisation, Geneva.

Page | 3891 WHO (2005). Nutrient in drinking water. Water, Sanitation and Health Protection and the Human Environment World Health Organisation, Geneva.

Yusuf, K. O., Adio-Yusuf, S. I. and Obalowu, R. O. (2019). Development of a simplified slow sand filter for water purification.
Journal of Applied Science and Environmental Management, 23 (3): 389393.

Yusuf, K. O. and Murtala, M. O. (2020). Development and performance evaluation of a portable household ceramic water filter with activated carbon and magnetic treatment unit. International Journal of Environmental Science and Technology, 17 (5): 1-10. 